\title{
Female Bareness in Print Advertisements: Do Religiosity and Gender Matter?
}

\author{
Nour El Houda Ben Amor ${ }^{1}$, Mohamed Skander Ghachem ${ }^{1}$, Karim Garrouch ${ }^{1} \&$ Mohamed Nabil Mzoughi ${ }^{2}$ \\ ${ }^{1}$ Institute of Management, Research Unit MaPReCOB, Sousse University, Sousse, Tunisia \\ ${ }^{2}$ Department of Marketing, College of Business Administration, King Saud University, Riyadh, Saudi Arabia \\ Correspondence: Mohamed Nabil Mzoughi, Department of Marketing, College of Business Administration, King \\ Saud University, Riyadh, Saudi Arabia. E-mail: teachershello@yahoo.fr
}

Received: January 23, 2014 Accepted: February 12, 2014 Online Published: May 21, 2014

doi:10.5539/ijms.v6n3p97

URL: http://dx.doi.org/10.5539/ijms.v6n3p97

\begin{abstract}
This paper studies Tunisian respondents' reactions to female bareness according to their gender and their level of religiosity. The purpose of the study is to construct a model describing the effect of the provocation, through female bareness, on viewer's reactions. The investigation is conducted in Tunisia. The results emphasize the moderating role of the gender and the positive impact of religiosity on negative emotions during an exposure to female bareness. The theoretical contributions of this research involve the mediating effect of the emotions; the survey shows that negative emotions play a mediator role in the persuasive processes.
\end{abstract}

Keywords: advertising, bareness, attitude, gender, religiosity, emotions

\section{Introduction}

Provocation attracts individuals' attention. Accordingly, it resolves saturation issues. Provocative advertising strategies use bareness, sexual images and insinuation. A large range of products takes advantage of this commercial stratagem in order to create a persuasive advertisement (Reichert, 2002; Reichert, Heckler, \& Jackson, 2001). Female bareness is used more than masculine bareness in advertising (Dudley, 1999; Soley \& Kurzbard, 1986; Reid, Salmon, \& Soley, 1984; Reidenbach \& Mc Cleary, 1983). The literature focuses essentially on the provocative aspect of bareness (Manceau \& Tissier-Desbordes, 2005; Pope, Voges, \& Brown, 2004), its attractive and emotional power (Judd \& Alexander, 1983; LaTour, 1990; Simpson, Horton, \& Brown, 1996), and its effects on the attitude (Dianoux \& Linhart, 2010; Duddley, 1999; LaTour \& Henthorne, 1993). Some deontological approaches raise issues about the morality of using bareness by advertisers. They examine how some individual differences (religiosity, ethical judgment, and sexual experience) affect the perception of bareness in TV commercials (Gould, 1994). Teleological approaches highlight the advantages and the disadvantages of advertisements including bareness sequences and their effects on consumers. In this perspective, two types of investigation are used; the first is qualitative and is based on analyzing the semiotic content of the stimulus. The second is quantitative and confirmatory; it integrates several demographic and individual variables such as age, gender, personality, and implication (Gould, 1994).

This paper questions the impact of using female bareness in commercials on consumers' emotions and attitudes, and investigates how gender and religiosity interfere in this relationship. It analyzes respondents' reactions toward female bareness according to their gender and their level of religiosity. The purpose of the study is to elaborate a model that highlights the effect of provocation, by means of female bareness, on viewers' reactions. The integration of religiosity allows a better understanding of the acceptance, or the disapproval, of advertisements containing female bareness scenes. Knowing the effect of religiosity, managers may avoid unsuitable choices and consider adapting the content of their commercials to the audience for a more efficient advertising strategy.

\section{Conceptual Framework}

\subsection{Female Bareness in Advertising: A Source of Provocation}

Bareness content in advertising is a provocative approach of creativity (Pope et al., 2004; Smith, Haugtvedt, Jadrich, \& Anton, 1995; Soley \& Kurzbard, 1986). It aims to catch viewers' attention by transcending social taboos (Sabri, 2012; Joannis, 1995). The type of feminine bareness in advertisements depends on the style of garment wore by the actors (Alexander \& Judd, 1983; Belch, Barbra, George, \& Koppman, 1981; Judd \& 
Alexander, 1983; Peterson \& Kerin, 1977; Sciglimpaglia, Belch, \& Cain, 1979; Simpson et al., 1996; Stedman 1969). In commercials, the bareness is presented according to two scenarios; the first is suggestive, with models wearing outfits that show only some parts of the body (short skirts, short shirts or t-shirts, tight or low-waist jeans, small beachwear, etc.). The second uses complete bareness (no clothes at all), without showing genitalia (Reichert, 2002).

Provocation refers to "a deliberate resort to stimulus in an advertising context aiming to shock, at least a part of the audience, through its level of difference, ambiguity or incongruity, and/or because it refers to moral values and taboos that are not usually broached in advertising" (Vézina \& Paul, 1997). Provocative messages are based on the theory of psychological persuasion. The provocative content depends on the purposes of the company, its reputation, the products that it provides and the characteristics of the target. It can also be inspired from some social, cultural, or political debates in the society.

Sexuality is a taboo topic in several countries. However, it is the bases of provocation strategies in many advertisements (Vézina \& Paul, 1997). This study focuses on the female bareness stimulus in advertising, which is not necessarily identified by a representation of a completely naked body. Parts of the chest, legs, or hips are considered as being bareness (Manceau \& Tissier-Desbordes, 2005).

Bareness has a physiological and an emotional impact. The provocation felt by an individual that watches a commercial containing a sensual or an erotic scene influences the formation of negative and positive emotions that are specific to the physiological arousal state: the arousal emotions (Aaker \& Burzonne, 1985; De Pelsmaker \& Geunes, 1996; De Pelsmacker \& Van Den Bergh, 1998; LaTour, 1990; LaTour \& Henthorne, 1994). Even though the integration of the bareness in advertisements aims the increase of the attention, the consumer might perceive this action as an aggression that could trigger negative emotional reactions (Tarrit, 1987).

\subsection{Emotional Responses to Provocative Advertisements: The Arousal Negative Affect}

Erotic advertisements generate a provocation that may trigger negative emotional responses (De Pelsmacker \& Van Den Bergh, 1996; Vézina \& Paul, 1997) and arousal emotional responses (LaTour and Henthorne, 1994). The emotions caused by sexual stimuli include components that relate to a physiological arousal. The erotic content of advertisements increases the viewers' attention more than it generates positive emotion (Alexander \& Judd, 1979; LaTour, Pitts, \& Snook-Luther, 1990).

\subsubsection{Negative Emotions (NE)}

The negative affect is the set of unpleasant feelings and emotions caused by an advertising exposure (Mackenzie, Lutz \& Belch, 1986). According to Huang (1997), it is useless to make a distinction between feelings and emotions. Hence, the negative affect is simply the set of negative emotions. A literature revue in marketing and psychology shows the existence of two main paradigms about the negative affect. The first is a discreet vision of the affect, according to which several types of negative affects exist. In this conception, the negative affect cannot be considered as global (Batra \& Ray, 1986). The second is an overall vision of the negative affect; it is a continuous approach of the emotions. It considers that a global negative affect can capture all the emotional responses of consumers (Huang, 1997). Both visions of negative affects coexist. They are generated simultaneously and the boundary between them is not obvious. The study of emotions according to a continuous approach seems to be simplistic and lacks external validity (De Barnier, 2002). The use of a discreet approach leads, also, to questionable results concerning the influence of emotions on the attitude toward the advertisement. This contradiction, emanating from the coexistence of several types of negative emotions, makes the isolation of the impact of each affect more complex (De Barnier, 2002).

According to Bagozzi (1993), "the specific and the global aspect of the negative affect are two complementary phenomena". The PANAS scale provided by Watson, Clark, and Tellegen, (1988) takes into account both aspects of the negative affect according to the sensitivity level of individuals. The types of negative emotions are distinguishable in the specific level and indistinguishable in the global negative emotion level. In the study were they develop the PANAS scale, Watson et al. (1988) distinguish between positive and negative affect by extracting a two-factor solution. The first factor is labeled as "the arousal negative affect" and the second as "the global positive affect". Nevertheless, nine negative items and three positive items loaded on the first factor. These findings suggest that the position of the items is not clear in the affective continuum (pleasant vs. unpleasant). Nevertheless, it is clear that these items represent a high affective arousal that alerts and attracts subject's attention.

\subsubsection{Arousal Emotions (AE)}

Arousal emotions generally refer to a physiological excitement that increases the attention and provokes emotional reactions (Holbrook \& Hirshman, 1982). The PANAS scale appraises the negative emotional responses and 
highlights the impact of the physiological arousal caused by advertisements (Huang 1997). The bidimensionnal perspective of the emotions gives emphasis to the positive and negative aspects of emotions (Brown, Homer, \& Inman, 1998; Edell \& Burke, 1987). According to Huang (1997), negative emotions integrate a component of arousal. Consequently, the study of the persuasive power of negative emotions leads to the exploration of the impact of arousal emotions: they form jointly the "arousal negative affect" (Huang, 1997).

\section{Hypothesis Development}

\subsection{The Impact of the Provocation on the Negative Emotions}

Studies on sensual messages show a significant variability in the results (Morrison \& Sherman, 1972). Some reveal that the erotic stimuli generate positive emotions (De Pelsmacker \& Geuens, 1996; De Pelsmacker \& Van Den Bergh, 1996; LaTour \& Henthorne, 1994); others show that eroticism stimulates negative emotional responses (Aaker \& Burzonne, 1985; De Pelsmacker \& Geunes, 1997; De Pelsmacker \& Van Den Bergh, 1998; LaTour \& Henthorne, 1993; Vézina \& Paul, 1997). The divergence of the results is caused by the methodological and the contextual differences of the researches. Although consumers appreciate provocative advertisements sometimes, they still can develop negative emotions toward the product (Alexander \& Judd, 1979). This study adopts the second and dominant vision that establishes a positive relationship between the provocation and the negative emotions; the higher is the degree of the provocation, the more the negative emotional responses increase.

H1: The provocation influences positively the NE.

\subsection{The Impact of the Provocation on the Arousal Emotions}

Sensual advertisements have a major impact on the arousal. These types of commercials produce a physiological arousal response (Belch et al., 1981; Peterson \& Kerin, 1977; LaTour, 1990; Morrison \& Sherman, 1972). They increase the arousal emotions, but do not necessarily generate positive emotions (Judd \& Alexander, 1983; Stedman, 1969). Stimulating the attention by an excessive use of bareness can have unfavorable consequences due to the predominance of negative emotions (LaTour, 1990; Richmond \& Hartman, 1982).

H2: The provocation has a positive effect on the AE.

\subsection{The Moderating Role of Gender}

According to several scholars, the acceptance or the disapproval of the bareness depends on some individual differences such as gender and religiosity (Alexender \& Judd, 1979; Black, Organ, \& Morton, 2010; LaTour, 1990; Morrison \& Sherman, 1972; Sciglimpaglia et al., 1979; Steadman, 1969). The tastes, the needs, and the perceptions of man and woman are not the same. They are a consequence of the morphological and the psychological differences characterizing each individual since the childhood. Many studies show that the gender has a significant influence on viewers' responses to the bareness in advertisements (Dianoux \& Linhart, 2010; Jeong \& Hwang, 2005; Nelson \& Pack, 2008; Sabri \& Obermiller, 2011). The use of the opposite sex in the commercial produces a very strong result (Liu, Li, \& Cheng, 2006; Reichert, LaTour, \& Kim, 2007; Reichert \& Fosu, 2005; Sengupta \& Dahl, 2008), particularly with regard to female bareness (Jeong \& Hwang, 2005). Studies conducted on the relationship between the consumers' gender and their attitudes toward the use of eroticism in advertisements state that women are more sensitive to erotic provocation (Dudley, 1999). The perception of advertisements and the generation of negative emotions and arousal vary according to the consumer's gender (Belch et al., 1981; Dudley, 1999; Judd \& Alexander, 1983; LaTour, 1990; Manceau \& Tissier-Desbordes, 1999; Reidenbach \& Mc Cleary, 1983; Sciglimpaglia et al., 1979). Women are more unfavourable to the use of sexuality in commercials (Johnson \& Satow; Wise \& Mirenski; in Dudley, 1999). They express more negative emotional responses than men do (Bello, Pitts, \& Etzel, 1983; LaTour, 1990; Peterson \& Kerin, 1977). The negative emotions felt toward female bareness engender a strong increase of arousal (Bello et al., 1983; LaTour, 1990), as well as a bad perception of the image of the brand (Peterson \& Kerin, 1977). In contrast, men are, in some cases, less unfavorable and even favorable to the use of nude women in advertisements. This affects positively their attitudes toward the advertisement and the brand (Peterson \& Kerin, 1977). Positive emotional reactions can emerge, followed by a more intense arousal (Bello et al., 1983; LaTour, 1990).

H3: Women feel more NE toward female bareness than men do.

H4: Men feel more AE toward female bareness than women do.

\subsection{The Moderating Role of Religiosity}

Religion affects consumers' attitudes, values and behaviors (Khraim, 2010; Moschis \& Ong, 2011; Fam, Waller, \& Erdogan, 2004). The mystical aspect of the religiosity explains the difficulty to adopt a universal definition of this concept and confines it to the practice of a religion. Yet, its complexity is far beyond this minimalist aspect 
(Singhapakdi et al., 2000). The religiosity is "a kind of an original quality of the human soul; an essential, and intrinsic component of the soul; a part of the structure of the human conscience; a fundamental part at the bases of the ontological structure; in a way, as one of the a priori of the empirical social life; something that precedes the attitudes" (Simmel, 1959). It is also considered as the moral predispositions of the individual that affects his attitude and behavior toward the use of bareness in the mass media (Choe \& Lau, 2010).

A relationship exists between the emotional structure of the individual and his religion. Faith is an emotional support against problems and difficult decisions during the stressful periods. It has an important influence on the values, the attitudes, and the decisions of consumers. The religiosity level of consumers has a significant impact on the efficiency of the advertisement. Unfortunately, marketing literature does not mention the nature of the relationship between emotions and religiosity. This is a consequence of the lack of studies on the religiosity concept in consumer behavior (Delener, 1994).

The individuals having a high level of religiosity are more conservative than others are (Barnett, Ken, \& Gene, 1996; Delener, 1994; Singhapakdi, Vittell, \& Franke, 1999). The higher the level of the religiosity of a person is, the more he/she adopts a traditional attitude, and the more important his/her sensitivity to the provocation is. This leads to stronger negative emotions and intense arousal feelings. Accordingly, religiosity has a positive impact on the development of the "arousal negative affect".

H5: The religiosity amplifies the NE felt toward bareness.

H6: The religiosity amplifies the AE felt toward bareness.

Either strong or weak, the religiosity specifies when and how the individuals are strongly affected by a sexual sequence in an ad, and to which extent they feel a strong intensity of negative emotions and arousal feelings. The following hypotheses are based on the works of Baron and Kenny (1986) who emphasize the moderating role of variables:

H7: Individuals with higher levels of religiosity feel more NE toward bareness than individuals with lower levels of religiosity do.

H8: Individuals with higher levels of religiosity feel more AE toward bareness than with lower levels of religiosity do.

\subsection{Female Bareness and Advertising Persuasion}

The responses of consumers to an advertisement are affected by the bareness that it contains (Dianoux \& Linhart, 2010; Nelson \& Pack, 2008). Provocative advertisements cause positive and negative emotions that affect the reactions of viewers (Batra \& Ray, 1986; Edell \& Burke, 1987). These reactions, having an influence on consumers' behaviour (Liu, Cheng, \& Li, 2009; Reichert et al., 2007), are measured by the attitude toward the advertisement (Bagozzi, Gopinath, \& Nyer, 1999; Brown \& Stayman, 1992; Mitchell \& Olson, 1981; Shimp, 1981). It is also suggested that the emotions and the attitudes of consumers affect their behaviour; particularly, when they are exposed to an advertisement (DeBarnier, 2002; Holbrook \& Hirschman, 1982). The attitude toward the advertisement $(\mathrm{Aad})$ and the attitude toward the brand $(\mathrm{Ab})$ are the two main indicators of the persuasive power of commercials (Batra \& Ray, 1986; Edell \& Burke, 1987; Holbrook \& Batra, 1987).

\subsubsection{Effect of Provocation on Attitudes}

The visual components of a provocative advertisement are negatively assessed. They affect the attitude toward the advertisement and the attitude toward the brand (Mitchell \& Olson, 1981; Mitchell, 1986). The negative impact of provocation on attitudes occurs via the negative emotions felt after viewing the advertisement (De Pelsmacker \& Van Den Bergh, (1996, 1998); Vézina \& Paul, 1997). Even though previous research shows that provocative advertisements have a negative impact on the attitude toward the advertisement and on the attitude toward the brand, this effect remains a controversy (LaTour \& Henthorne, 1994).

H9: Provocation influences negatively the Aad.

H10: Provocation influences negatively the Ab.

\subsubsection{Effect of Emotions on Attitudes: The Mediator Role of Emotions and Attitude toward the Advertisement}

There is a consensus about the existence of a relationship between emotion and attitude (Aaker et al., 1986; Batra \& Ray, 1986; Belch et al., 1981; Burke \& Edell, 1989). However, scholars disagree about the nature of this relationship (DeBarnier, 2002; Edell \& Burke, 1987; Holbrook \& Batra, 1987; Homer \& Yoon, 1992; Huang, 1997; Mackenzie et al., 1986; Stayman, Douglas, \& Aaker, 1988). Two main approaches co-exist: the first considers that the relationship between the two concepts is direct (Aaker, Stayman, \& Hagerty, 1986; Batra \& Ray, 1986); the 
second suggests the mediation of the cognitive dimension of the attitude (Burke \& Edell, 1989; Edell \& Burke, 1987). In addition, several researchers state that the attitude toward the advertisement has a positive effect on the attitude toward the brand (Bagozzi et al., 1999; Edell \& Burke, 1986; Gardner, 1985; MacInnis \& Jaworski, 1889; Mackenzie et al., 1986; Mitchell \& Olson, 1981; Mitchell, 1986; Park \& Young, 1986). According to Shimps (1981), the transfer between the two concepts occurs through a conditioning process.

As shown previously, several studies support that the attitude toward the advertisement mediates the relationship between the emotional responses and the attitude toward the brand. However, there is a controversy about the nature of this mediation. Some researchers advocate a partial mediation approach, according to which the attitude toward the advertisement does not integrate all the emotional responses of the individual (Edell \& Burke, 1987; Satyman et al., 1988). Thus, the effect of the emotions on the attitude toward the brand is both direct and indirect (through the attitude toward the advertisement). Other scholars suggest that the attitude toward the advertisement captures all the emotions felt by the individual during the advertising exposure and that the effect of the emotions on the attitude toward the brand is definitely not direct (Batra \& Ray, 1986; Holbrook \& Batra, 1987). Therefore, measuring the attitude toward the advertisement helps to forecast the effect of the emotions on the attitude toward the brand.

This study focuses on the efficiency of the affective aspect of commercials. It assumes a direct relationship between the emotions and the attitude toward the advertisement. Thus, provocative advertisements cause negative emotions, which, in turn, negatively affect viewers' attitudes (Mitchell, 1986; Mitchell \& Olson, 1981).

H11: The NE have a negative impact on the Aad.

H12: The NE have a negative impact on the Ab.

H13: The NE mediate the relationship between the provocation and the Aad.

Huang (1997) highlights the role of attention. He advocates that the attention generate favorable opinions about the advertisement. According to Aaker et al. (1986), the attention has a positive influence on the desirability of the product or the brand. Thus, the arousal emotions play a major role in the advertising persuasion process (Holbrook \& Hirshman, 1982; Singh \& Churchill, 1987).

H14: The AE have a positive impact on the Aad.

H15: The AE have a positive impact on the Ab.

The arousal state or the level of attention of the viewer (caused by the exposure to an advertisement) is one of the best ways to predict how the individuals would perceive the message (LaTour et al., 1990). Accordingly, the effect of provocative commercials on the attitude toward the advertisement is mediated by the arousal (LaTour et al., 1990; Thayer, 1986).

H16: The AE mediate the relationship between the provocation and the Aad.

Stayman et al. (1988) show that the emotions are related more to the attitude toward the advertisement than to the attitude toward the brand. They support the idea advocating that attitude toward the advertisement captures all the emotional responses. The following hypotheses are proposed in order to investigate the veracity of these statements:

H17: The Aad has a positive impact on the Ab.

H18: The Aad mediates the relationship between the NE and the Ab.

H19: The Aad mediates the relationship between the (AE) and the Ab.

\section{Methodology}

\subsection{Sampling and Data Collection}

Two chocolate prints advertisements containing female nudity were chosen. The first one include a partially undressed female model, the second incorporate a female nude breast. In order to avoid a potential brand knowledge effect in the advertising persuasion process and to guarantee a bigger emotional impact, the selected brands were not known by the participants (Derbaix, 1995; Johnson \& Eagly, 1989). Data was collected through questionnaire survey. Electronic and face-to-face modes of questionnaire administration were conducted. A pre-test amongst 20 participants was undertaken to minimize the research errors by testing the reliability of questionnaire (Evrard, Pras, \& Roux, 2003). A convenience sampling was conducted in this research. The size of the survey sample included 183 respondents ( 78 men and 105 women). The majority of Tunisian participants were Muslim, living in the north of the country and in the range of 18 to 34 years old. 


\subsection{Measures}

Scales were selected from the literature. Five point scales were used (likert and semantic). Provocation is measured by a fifteen-item Likert-scale, which was developed by De Pelsmacker and Van Den Bergh (1996). The Religious Commitment Inventory (RCI-10) developed by Worthington et al. (2003) was used to measure religiosity. This scale allows to measure motivational and behavioral commitment to a religious value system. The emotions are assessed through the PANAS scale (Watson et al., 1988). Subjects' attitudes toward the ad were measured using the scale of Holbrook and Batra's (1987) and the scale of Shiv, Edell, and Payne (1997) was used to measure the attitude toward the brand.

\subsection{Data Analysis Method}

The reliability and the validity of the measures were verified in two steps: A descriptive analysis (SPSS) and a first order confirmatory analysis (Amos) (Roussel, Durrieu, Campoy, \& El Akremi, 2002). The Principal component analysis (PCA) showed the existence of height factors. The confirmatory factor analysis conserved only six factors.

The evaluation of the relationships and the parameters within the theoretical framework, as well as the model fit with the numerical data, were performed by the use of Amos. The moderating variable (religiosity) divided the sample into two categories: individuals with high levels of religiosity and individuals with low levels of religiosity. The analysis of the moderating effect of gender and religiosity is achieved by comparing the strength of the relationship between the independent variable (provocation) and the dependent variables (negative emotions and arousal emotions) in the different groups.

\section{Results Analysis}

\subsection{Scales' Dimensionality and Reliability}

The reliability was measured using the Cronbach's alpha coefficient which indicates the level of internal items consistency: $0.6<$ Cronbach's alpha $<0.8$ accepted in exploratory study and Cronbach's alpha $>0.8$ preferred in confirmatory study (Evrard et al., 2003). The Cronbach's alpha coefficient was ranged from 0,647 to 0,963; thus, the scales used for this study were considered to be reliable (DeVellis, 2012). The extraction of all the items are higher than 0.5 (Evrard et al., 2003).

\subsubsection{Provocation}

The factor analysis extracted two factors: the irritating dimension and the attractive dimension. The Cronbach's alphas of the two dimensions confirmed the reliability of the scale ( 0.93 for the "irritating" dimension and 0.75 for the "attractive" dimension).

\subsubsection{Religiosity}

The scale of religiosity is bi-dimensional. The factorial weights of the ten items that were associated with this construct were superior to 0.5 . The Cronbach's alpha of the cognitive aspect of religiosity factor was 0.88 and of the behavioral aspect of religiosity factor was 0.80 . Seven items loaded with the first factor and three on the second.

\subsubsection{Emotions}

The factor analysis highlighted three dimensions: the "positive emotions", the "negative emotions" (NE) and the "arousal emotions" (AE). The study focused particularly on the "negative emotions" and the "arousal emotions". Cronbach's alphas were 0.96 for the NE factor and 0.64 for $\mathrm{AE}$ factor.

\subsubsection{The Attitude toward the Advertisement}

The factor analysis confirmed the existence of one dimension. The Cronbach's alpha value was 0.92 .

\subsubsection{The Attitude toward the Brand}

This variable is one-dimensional. The dimension of the attitude toward the brand provided an alpha of 0.94 .

\subsection{Confirmatory Factor Analysis}

A first confirmatory analysis was conducted. The analysis of the provocation scale the Jöreskog's Rhô associate with the attractive dimension of provocation was 0.513 which is under the threshold of 0.7 . The bi-dimensional conception of provocation, founded by the exploratory analysis, was abandoned for the benefit of a one dimensional structure. This finding converges with the theoretical conception of provocation (De Pelsmacker \& Van Den Bergh, 1996). The analysis of the emotions' scale showed that the Jöreskog's Rhô value related with the arousal emotions dimension was $0.55(<0.7)$. Thus, only the negative emotions dimension was conserved. 
In the final confirmatory analysis only six factors were kept. Reliability was verified by Jöreskog's Rhô, its accepted value is 0.7 or above for a construct (Fornell et Larcker, 1981; Didellon \& Valette-Florence, 1996). The estimate standardized regression weights of all the items are higher than 0.5 and the Critical Ratio (CR) associated to each factorial contribution is above 1.96 as recommended by (Byrne, 2001). Convergent validity was assessed by calculating the Rhô of Convergent Validity ( $\rho v c)$. According to Fornell and Larker (1981), this index must equal or exceed the value of 0.5 for each construct. The Discriminant Validity was tested by verifying that the average variance extracted by each construct was greater than the squared structural link between all other constructs (Fornell \& Larker, 1981).

\subsection{Global Significance and Model Fit}

The first step was to make sure that there were no negative variance values and that all the standardized coefficients were above 1 . The second was to verify that the theoretical model fits the empirical data. Despite the exploratory nature and the complexity of the model (due to the integration of the religiosity concept), the fit indices showed that the model fits the empirical data. Values are reliable: $\mathrm{X}^{2} / \mathrm{df}<2$ (E.J Pedhazur \& L. Pedhazur-Schmelkin, in Roussel et al., 2002). The RMSEA approaches the value of 0.05 which shows excellent fit (Steiger, 1990; MacCallum, Browne \& Sugawara, in Byrne, 2001). The GFI is above 0.90, it represents an acceptable fit (Jöreskog \& Sorbom, 1989). Furthermore, the CFI is above the threshold of 0.9 (Bentler, 1990) and the NFI is above 0.8 (James, Mulaik, \& Brett, 1982). However, the initial model $\mathrm{M}_{0}$ shows the existence of a set of not significant effects as the value of Critical Ratio was lower than 1.96. The final model M1 is obtained by removing the non significant relations through a step by step procedure.

\subsection{Hypothesis Testing}

After the confirmatory analysis only the negative emotions dimension was kept. Thus, all the hypotheses pertaining to the arousal emotions dimension are not tested (i.e., H2, H4, H6, H8, H14, H15, H16 and H19).

\subsubsection{Provocation and Emotions}

Provocation has a positive impact on NE $(\beta=0.701 ; t=8.777>1.96)$. It seems that the more provocative is the advertisement, the more the subjects that were exposed to such commercial develop negative emotions. Accordingly, $\mathrm{H} 1$ is supported.

\subsubsection{Analysis of the Moderating Effect of Gender}

A first step to verify a moderator role of the gender is to compare two models: the fully constrained model and the unconstrained model. The Chi-square difference test confirms the existence of a significant effect. It shows that the gender moderates the relationship between the provocation and the NE. In both groups (women and men), the provocation had a direct positive impact on the NE (respectively, $\beta_{\text {Women }}=0.695 ; \mathrm{t}_{\text {Women }}=6.411 ; \beta_{\text {Men }}=0.733$; $\left.\mathrm{t}_{\text {Men }}=6.173\right)$. Thus, men developed more NE toward female bareness than women did $\left(\beta\right.$ women $\left.<\beta_{\text {Men }}\right)$. The regression coefficient change between groups. It is necessary to examine if this difference is significant. The coefficient $\beta_{\text {Men }}$ is significantly different from $\beta_{\text {Women }}(|\mathrm{T}|=2,757>1.96)$. H3 is rejected.

\subsubsection{Religiosity and Emotions}

The results showed that the cognitive aspect of the religiosity had a positive impact on the NE $(\beta=0.164 ; \mathrm{t}=$ 2.693). The behavioral aspect of religiosity had no significant impact on the NE. H5 is partially supported.

\subsubsection{Analysis of the Moderating Effect of Religiosity}

The Chi-square difference test between the fully constrained model and the unconstrained model is not statistically significant. The provocation had a positive impact on the NE in the group of individuals with high levels of religiosity $\left(\beta_{R}=0.641 ; t=5.655\right)$ and in the group of individuals with low levels of religiosity $\left(\beta_{\mathrm{r}}=0.601\right.$; $t=5.5057)$. The respondents from the first group felt more $N E$ toward female bareness $\left(\beta_{R}>\beta_{r}\right)$. The examination of a test for a difference in the coefficient between the two groups showed that a coefficient $\beta_{\mathrm{R}}$ is not significantly different from $\beta_{\mathrm{r}}(|\mathrm{T}|=0.503<1.96)$. $\mathrm{H} 7$ is rejected.

\subsubsection{Provocation and Attitudes}

The results showed that the provocation had a negative impact on the Aad $(\beta=-0.414 ; \mathrm{t}=-3.819)$. The more the provocation of the advertisement increases, the more the attitude toward it is unfavorable. H9 is supported. However, the findings revealed that the provocation had no significant effect on the Ab. H10 is rejected.

\subsubsection{Negative Emotions and Attitudes}

The NE had a negative effect on the Aad $(\beta=-0.253 ; \mathrm{t}=2.394)$. The more the NE increase, the more the negative Aad becomes intense. H11 is supported. Conversely, the NE did not have a direct effect on the Ab. H12 is rejected. 


\subsubsection{The Mediating Effects of the Negative Emotions}

The result showed that the total negative effect of the provocation on the Aad $(\beta=-0,592 ; p$-value $=0.018)$ stem from a significant direct $(\beta=-0,415$; $p$-value $=0.013)$ and a significant indirect negative effect $(\beta=-0,177$, $\mathrm{p}$-value $=0.013)$. The $(\mathrm{NE})$ play a mediating role in the relationship between the provocation and the Aad. This mediation is partial. H13 is partially supported.

\subsubsection{Attitude toward the Advertisement and Attitude toward the Brand}

The (Aad) had a positive effect on the attitude toward the brand $(\beta=0.750 ; t=11.338)$. A favorable (Aad) has a positive impact on the attitude toward the brand. This means that if the subject liked the advertisement, he (or she) also liked the brand. H17 is confirmed.

\subsubsection{The Mediating Effect of the Attitude toward the Advertisement}

The NE did not have a significant direct effect on the Ab. H12 is rejected. The Aad does not mediate the relationship between the $\mathrm{NE}$ and the $\mathrm{Ab}$. $\mathrm{H} 18$ is rejected.

\section{Discussion and Implications}

This research contributes to a better understanding of the acceptance of the female bareness in advertising and of the concepts that are involved in this process. It extends the persuasion model proposed by Holbrook and Batra (1987) through the integration of several others constructs such as the provocation, the gender and the religiosity.

The results show that, during an exposure to the female bareness, the gender constitutes a moderating variable. This finding is consistent with previous researches (Reichert et al., 2007; Ben Amor, 2005; Dudley, 1999; Simpson et al., 1996; Smith et al., 1995; La Tour et Henthorne, 1993; Sciglimpaglia et al.; Belch et al.; in La Tour et al., 1990; Judd et Alexander, in La Tour 1990; La Tour, 1990; Reidenbach et Mc Cleary, 1983; Peterson et Kerin, 1977).

In this study, men developed more negative emotions than women did. This outcome is inconsistent with previous researches (Bello et al., 1983; LaTour, 1990; Peterson et Kerin, in Reidenback \& Mc Cleary, 1989) but confirms the results found in a recent study conducted in Tunisia (Ben Amor, 2014). The difference between these findings may emanate from a difference in the cultural context, in the nature of the stimuli used, or in the measuring instruments used by these authors. The provocation by female bareness seems to be a bigger source of annoyance for men than for women respondents. The state of annoyance is translated by a proliferation of negative feelings. The latter can probably be decreased amongst women by the preference they have for a certain type of product with regard to men (Wansink, Cheney, \& Chan, 2003).

The research demonstrates that higher religiosity level result in more negative emotions and that the individuals with high levels of religiosity develop more negative emotions than the individuals with low levels of religiosity do. This outcome supports the assumptions made by Delener (1994) about the influence of the religiosity level on the emotions. Nevertheless, the religiosity does not play a moderating role between the provocation and the negative emotions because the difference between the groups (low religiosity/ high religiosity) was not statistically significant.

The acceptance or the rejection of the female bareness in advertising depends on the characteristics of the target. The suitable dosage of bareness that would be integrated in the advertisement requires a survey of the population. This should predict the specific reactions toward erotic stimuli (LaTour, 1990).

According to the results of this research, advertisers should reduce the provocation level of commercial with sensual. It would decrease the risk of hurting the sensitivity of individuals and avoid the creation of negative emotions. Furthermore, the female bareness associated to a chocolate product in advertisements is more accepted by women than by men. Advertising agencies should reduce the use of female bareness when their target is, mainly, composed of men.

Overall, the female bareness should be used with caution in advertising. Professionals need to identify, through different existing test methods, the limit above which it is perceived as excessive by the target (Alexander \& Judd, 1979; LaTour et al., 1990). It is necessary to find the right dosage that does not invert the positive effect of the provocation.

The theoretical contributions of this research involve the mediating effect of the emotions; the survey shows that the negative emotions mediate the relationship between the provocation and the attitude toward the advertisement. They hinder the formation of an unfavorable attitude toward the advertisement.

With reference to the effect of the attitude toward the advertisement on the attitude toward the brand, it seems that 
there is an affect transfer that is expressed by the existence of a strong relationship between these two variables (Mackenzie et al., 1986; Pham et al., 2013). These results confirm that the attitudes are an indicator of the efficiency of the copy strategy of the advertisement and, more specifically, of its persuasive power (Wiles \& Cornwell, 1990).

The methodological contribution of this survey involves the choice to resort to a diversified non student sample. The use of students for empirical studies is controversial (Calder \& Tybout, 1999; Calder, Phillips, \& Tybout, 1983; Lynch, 1999), even if scholars consent that students' samples are appropriate for theory testing (Peterson, 2001; Gopalakrishna \& Goldsmith, 2008). However, they all admit that samples of greater external validity need to be used to validate the findings of such studies.

\section{Limitations and Future Researches}

The erotic advertisement may trigger a discomfort feeling for some respondents, which can cause a bias in the information that they provide. In addition, the context of the research may prevent some individuals from disclosing a part of their emotional reactions. Future researches could consider the integration of other variables that could have a moderating impact on the relationship between the provocation and the emotions such as the involvement toward products. They could also investigate a larger sample by surveying different age categories and populations practicing other religions. A cross-cultural (or inter-religious) approach can reveal other aspects that would enhance the comprehension of the acceptance of bareness in advertisements within different population Finally, the congruence between the type of products and sensual contents is an important issue that needs further investigation (Pack \& Nelson, 2007; Sherman \& Quester, 2005).

\section{Acknowledgment}

The Researchers would like to thank the Deanship of Scientific Research at King Saud University represented by the research center at CBA for supporting this research financially.

\section{References}

Aaker, D. A., \& Burzzone, D. E. (1985). Causes of irritation in advertising. Journal of Marketing, 49(2), 47-57. http://dx.doi.org/10.2307/1251564

Aaker, D. A., Stayman D. M., \& Hagerty, M. R. (1986). Warmth in advertising: measurement, impact and sequence effects. Journal of Consumer Research, 12(4), 365-381. http://dx.doi.org/10.1086/208524

Alexander, M. W., \& Judd, B. Jr. (1979). Do nudes in ads enhance brand recall? Journal of Advertising Research, $18(1), 47-50$.

Bagozzi, R. P. (1993). An examination of psychometric properties of measure of negative affect in the Panas-X scale. Journal of Personality and Social Psychology, 65(4), 836-851. http://dx.doi.org/10.1037/0022-3514.65.4.836

Bagozzi, R. P., Gopinath, M., \& Nyer, P. U. (1999). The role of emotion in marketing. Journal of the Academy of Marketing Science, 27(2), 184-206. http://dx.doi.org/10.1177/0092070399272005

Barnett, T., Ken, B., \& Gene, B. (1996). Religiosity, Ethical ideology and intentions to report a Peer's wrongdoing. Journal of Business Ethics, 15(11), 1161-1174. http://dx.doi.org/10.1007/BF00412815

Baron, M. R., \& Kenny, A. D. (1986). The moderator-Mediator variable distinction in social psychological research: conceptual, strategic and statistical considerations. Journal of Personality and Social Psychology, 51(6), 1173-1182. http://dx.doi.org/10.1037/0022-3514.51.6.1173

Batra, R., \& Ray, M. L. (1986). Affective responses mediating acceptance of advertising. Journal of Consumer Research, 13(2), 234-249. http://dx.doi.org/10.1086/209063

Belch, M. A., Barbra, E. H., George, E. B. \& Koppman, J. (1981). Psychophysiological and cognitive response to sex in advertising. Advances in Consumer Research, 9, 424-427.

Bello, D. C., Pitts, R. E. \& Etzel, M. J. (1983). The Communications Effects of Controversial Sexual Content in Television Programs and Commercials. Journal of Advertising, 12(3), 32-42. http://dx.doi.org/10.1080/00913367.1983.10672846

Ben Amor, N. H. (2014). Sensualité féminine et imagerie mentale visuelle: Impact sur les réponses émotionnelles, attitudinales et comportementales. Thesis. Higher Institute of Management of Tunis.

Bentler, P. M. (1990). Comparative fit Index in structural models. Psychological Bulletin, 107(2), 238-246. http://dx.doi.org/10.1037/0033-2909.107.2.238 
Black, R. I., Organ, C. G., \& Morton, P. (2010). The effect of personality on response to sexual appeals. European Journal of Marketing, 44(9/10), 1453. http://dx.doi.org/10.1108/03090561011062925

Brown, P. S., Homer, M. P., \& Inman, J. J. (1998). A meta-analysis of relationships between ad-evoked feeling and advertising responses. Journal of Marketing Research, 35(1), 114-126. http://dx.doi.org/10.2307/3151934

Burke, M. C., \& Edell, J. A. (1989). The impact of feeling on ad-based affect and cognition. Journal of Marketing Research, 26(1), 69-83. http://dx.doi.org/10.2307/3172670

Byrne, B. M. (2001). Structural equation modeling with Amos, basic concepts, applications and programming. London: Lawrence Erlbaum Associates Publishers.

Calder, B. J., \& Tybout, M. (1999). A vision of theory, research, and the future of business schools. Journal of the Academy of Marketing Science, 27, 359-366. http://dx.doi.org/10.1177/0092070399273006

Calder, B. J., Phillips, L. W., \& Tybout, A. M. (1983). Beyond external validity. Journal of Consumers Research, 10, 112-114. http://dx.doi.org/10.1086/208950

Choe, K. L., \& Lau, T. C. (2010). Attitude towards business ethics: examining the influence of religiosity, gender and education levels. International Journal of Marketing Studies, 2(1), 225-232.

Davis, F. B. (1964). Educational Measurements and their Interpretation. Belmont, California: Wadsworth.

De Pelsmacker, P., \& Geuens, M. (1996). The communication effect of warmth, eroticism and humor in alcohol print advertisements. Journal of Marketing Communication, 2(4), 247-262. http://dx.doi.org/10.1080/135272696346088

De Pelsmacker, P., \& Geuens, M. (1997). The use of different types of emotional appeals and information cues in magazine advertisements over time and the degree of overall similarity of strategy: the Belgian case. International Journal of Advertising, 16(2), 123-147.

De Pelsmacker, P., \& Van Den Bergh, J. (1996). The communication effects of provocation in print advertising. International Journal of Advertising, 15(18), 203-221.

De Pelsmacker, P., \& Van Den Bergh, J. (1998). Advertising content and irritation: A study of 226 TV commercial. Journal of International Consumer Marketing, 10(4), 5-27. http://dx.doi.org/10.1300/J046v10n04_02

DeBarnier, V. (2002). Le rôle des émotions sur l'attitude envers la marque (Ab) pour une médiation totale de l'attitude envers le message (Aad). Recherche et Application en Marketing, 17(3), 81-99. http://dx.doi.org/10.1177/076737010201700306

Delener, N. (1994). Religious contrasts in consumer decision behaviour patterns: their dimensions and marketing implications. European Journal of Marketing, 28(5), 36-46. http://dx.doi.org/10.1108/03090569410062023

Demnati, H. (2003). La genèse de la fidélité des consommateurs: Intégration nomologique avec incorporation de la religiosité et application des méthodes d'équations structurelles. Master Dissertation in Management, Higher Institute of Management of Tunis.

Derbaix, C. M. (1995). The impact of affective reactions on attitudes toward the advertisement and the brand: A step toward ecological validity. Journal of Marketing Research, 32(4), 470-479. http://dx.doi.org/10.2307/3152182

DeVellis, R. F. (2012). Scale development: Theory and application. Retrieved from http://books.google.tn/books?id=vmwBHYuchfAC\&printsec=frontcover\&hl=fr\&source=gbs_atb\#v=onepa ge $\& \mathrm{q}=\mathrm{alpha} \% 2009 \& \mathrm{f}=$ false

Dianoux, C., \& Linhart, Z. (2010). The effectiveness of female bareness in advertising in three European countries. International Marketing Review, 27(5), 562. http://dx.doi.org/10.1108/02651331011076590

Didellon, L., \& Valette-Florence, P. (1996). L'utilisation des indices d'ajustement dans les modèles d'équations structurelles: présentation et recommandation d'usage. Actes des XIIIèmes journées nationales des IAE.

Dudley, C. S. (1999). Consumer attitudes toward bareness in advertising. Journal of Marketing Theory and Practice, 7(4), 89-96.

Edell, J. A., \& Burke, C. M. (1987). The power of feeling in understanding advertising effects. Journal of Consumer Research, 14(3), 421-433. http://dx.doi.org/10.1086/209124

Evrard, Y., Pras, B., \& Roux, E. (2003). Market: Etudes et Recherche en Marketing. Paris: Dunod. 
Fam K. S., Waller, D. S., \& Erdogan, B. Z. (2004). The influence of religion on attitudes towards the advertising of controversial products. European Journal of Marketing, 38(5/6), 537-555. http://dx.doi.org/10.1108/03090560410529204

Fornell, C., \& Larcker, D. F. (1981). Evaluating structural equation models with unobservable variables and measurement error. Journal of Marketing Research, 18(1), 39-50. http://dx.doi.org/10.2307/3151312

Gardner, M. P. (1985). Mood states and consumer behavior: A critical review. Journal of Consumer Research, 12(3), 281-300. http://dx.doi.org/10.1086/208516

Gopalakrishna, P. K., \& Goldsmithb, R. E. (2008). How brand attribute typicality and consumer commitment moderate the influence of comparative advertising. Journal of Business Research, 61(9), 933-941. http://dx.doi.org/10.1016/j.jbusres.2007.10.002

Gould, S. J. (1994). Sexuality and ethics in advertising: a framework and research agenda. Journal of Advertising, 23(3), 81-89. http://dx.doi.org/10.1080/00913367.1994.10673452

Holbrook, M. B., \& Batra, R. (1987). Assessing the role of emotions as mediators of consumer responses to advertising. Journal of Consumer Research, 14(3), 404-420. http://dx.doi.org/10.1086/209123

Holbrook, M. B., \& Hirschman, E. C. (1982). The experiential aspect of consumption, consumer fantasies: feeling and fun. Journal of Consumer Research, 9(2), 132-142. http://dx.doi.org/10.1086/208906

Homer, P. M., \& Yoon, S. G. (1992). Message framing and the interrelationship among Ad-based feelings, affect, and cognition. Journal of Advertising, 21(1), 19-33. http://dx.doi.org/10.1080/00913367.1992.10673357

Huang, M. H. (1997). Is negative affect in advertising general or specific? A comparison of three functional forms. $\begin{array}{llll}\text { Psychology and } \quad \text { Marketing, 223-240. } & \text { 14(3), }\end{array}$ http://dx.doi.org/10.1002/(SICI)1520-6793(199705)14:3<223::AID-MAR2>3.0.CO;2-D

James, L. R., Mulaik, S. A., \& Brett, J. M. (1982): Causal Analysis: assumptions, models and data. Beverly Hills, CA: Sage.

Jeong, S. H., \& Hwang, Y. R. (2005). Persuasive Effects of Bareness in Print Advertising: The Moderating Role of Viewer Gender and Degree of Bareness. The annual meeting of the International Communication Association, Sheraton New York. Retrieved from http://www.allacademic.com/meta/p13246_index.html

Joannis, H. (1995). De la stratégie marketing à la création publicitaire. Paris: Dunod.

Johnson, B. T., \& Eagly, A. H. (1989). Effect of involvement on persuasion: a meta-analysis. Psychological Bulletin, 106(2), 290-314. http://dx.doi.org/10.1037/0033-2909.106.2.290

Joreskog, K. G. (1971). Statistical analysis of sets of congeneric tests. Psychometrika, 36(2), 109-133. http://dx.doi.org/10.1007/BF02291393

Judd, B. Jr., \& Alexander, M. W. (1983). On the reduced effectiveness of some sexually suggestive ads. Journal of Academy of Marketing Science, 11(1/2), 156-168. http://dx.doi.org/10.1007/BF02721868

Kelloway, E. K. (1998). Using Lisrel for Structural Equations Modelling: A Researcher's Guide. London: Sage publications.

Khraim, H. (2010). Measuring religiosity in consumer research from Islamic perspective. International Journal of Marketing Studies, 2(2), 166-179.

LaTour, M. S. (1990). Female bareness in print advertising: Analysis of gender differences in arousal and Ad response. Psychology and Marketing, 7(1), 65-81. http://dx.doi.org/10.1002/mar.4220070106

LaTour, M. S., \& Henthorne, T. L. (1993). Femal bareness attitudes toward the ad and the brand, and implications for advertising strategy. The Journal of Consumer Marketing, 10(3), 25-32. http://dx.doi.org/10.1108/07363769310041956

LaTour, M. S., \& Henthorne, T. L. (1994). Ethical judgements of sexual appeals in print advertising. Journal of Advertising, 23(81), 140.

LaTour, M. S., Pitts, R. E., \& Snook Luther, D. C. (1990). Female bareness, arousal and Ad response: An experimental investigation. Journal of Marketing, 19(4), 51-62.

Liu, F., Cheng, H., \& Li, J. (2009). Consumer responses to sex appeal advertising: a cross cultural study. International Marketing Review, 26(4/5), 501. http://dx.doi.org/10.1108/02651330910972002 
Liu, F., Li, J., \& Cheng, H. (2006). Gender differences in Chinese consumers' responses. Asia Pacific Journal of Marketing and Logistic, 18(1), 9. http://dx.doi.org/10.1108/13555850610641064

Lynch, J. G. (1999). Theory and external validity. Journal of the Academy of Marketing Science, 27, 367-376. http://dx.doi.org/10.1177/0092070399273007

MacInnis, D. J., \& Jaworski, B. J. (1989). Information processing from advertisements: toward an integrative framework. Journal of Marketing, 53(4), 1-23. http://dx.doi.org/10.2307/1251376

Mackenzie, S. B., Lutz, L. R., \& Belch, G. E. (1986). The role attitude toward ad as a mediator of advertising effectiveness: test of completing explanations. Journal of Marketing Research, 23(2), 130-143. http://dx.doi.org/10.2307/3151660

Manceau, D., \& Tessier-Desbordes, E. (1999). La perception des tabous dans la publicité: impact des variables socio-démographiques. Décision Marketing, 16, 17-23.

Manceau, D., \& Tessier-Desbordes, E. (2005). La réception de la représentation de la nudité en publicité. Provocation ou esthétisme. Revue Française de Marketing, 201(1/5), 85-98.

Mitchell, A. A. (1986). The effect of verbal and visual components of advertisements on brand attitudes an attitude toward advertisement. Journal of Consumer Research, 13(1), 12-24. http://dx.doi.org/10.1086/209044

Mitchell, A. A., \& Olson, J. C. (1981). Are products attribute beliefs the only mediator of advertising effects on brand attitude? Journal of Marketing Research, 18(1), 318-322. http://dx.doi.org/10.2307/3150973

Mokhlis, S. (2009). Relevancy and measurement of religiosity in consumer behavior research. International Business Research, 2(3), 75-84.

Morrison, B. J., \& Sherman, R. C. (1972). Advertisement complexity and looking time. Journal of Marketing Research, 9(4), 396-400. http://dx.doi.org/10.2307/3149302

Moschis, P. G., \& Ong, F. S. (2011). Religiosity and consumer behavior of older adults: a study of sub cultural influences in Malaysia. Journal of Consumer Behaviour, 10(1), 8. http://dx.doi.org/10.1002/cb.342

Murphy, K. R., \& Davidshofer, C. O. (1988). Psychological Testing: Principles and Applications. New Jersey: Prentice-Hall.

Nelson, R. M., \& Pack, H. J. (2008). Bareness of female and male models in prime time Tv advertising across $\begin{array}{lllll}\text { seven } & \text { countries. International Journal of Advertising, } & \text { 27(5), } & 715 .\end{array}$ http://dx.doi.org/10.2501/S0265048708080281

Nunnally, J. C. (1967). Psychometric Theory. New York: McGraw-Hill.

Pack, H. J., \& Nelson, R. M. (2007). A cross-cultural and cross-media comparison of female bareness in advertising. Journal of Promotion Management, 13(1/2), 145. http://dx.doi.org/10.1300/J057v13n01_10

Park, O., \& Young, S. (1986). Consumer response to television commercials the impact of involvement and background music on brand attitude formation. Journal of Marketing Research, 23(1), 11-24. http://dx.doi.org/10.2307/3151772

Peterson, R. A. (2001). On the use of college students in social science research: insights from a second order meta-analysis. Journal of Consumers Research, 28(3), 450-461. http://dx.doi.org/10.1086/323732

Peterson, R. A., \& Kerin, R. A. (1977). The Female Role in Advertisements: Some Experimental Evidence. Journal of Marketing, 41(1), 59-63. http://dx.doi.org/10.2307/1250235

Pham, M. T., Geuens, M., \& De Pelsmacker, P. (2013). The influence of ad-evoked feelings on brand evaluations: Empirical generalizations from consumer responses to more than $1000 \mathrm{Tv}$ commercials. International Journal of Research in Marketing. http://dx.doi.org/10.1016/j.jiresmar.2013.04.004

Pope, N. K., Voges, K. E., \& Brown, M. R. (2004). The effect of provocation in the form of mild erotica on attitude to the ad and corporate image. Journal of Advertising, 33(1), 69-82. http://dx.doi.org/10.1080/00913367.2004.10639154

Reichert, T. (2002). Sex in advertising research: A review of content, effects, and functions of sexual information in consumer advertising. Annual Review of sex research, 13, 241-273.

Reichert, T., \& Fosu, I. (2005). Women's responses to sex in advertising: examining the effect of women's sexual self-schema on responses to sexual content in commercials. Journal of Promotion Management, 11(2/3), 143. http://dx.doi.org/10.1300/J057v11n02_10 
Reichert, T., Heckler, S. E., \& Jackson, S. (2001). The effect of sexual social marketing appeals on cognitive processing and persuasion. Journal of Advertising, 30(1), 17-27. http://dx.doi.org/10.1080/00913367.2001.10673628

Reichert, T., LaTour, M., \& Kim, J. K. (2007). Assessing the influence of gender and sexual self-schema on affective responses to sexual content in advertising. Journal of Current Issues and Research in Advertising, 29(2), 63. http://dx.doi.org/10.1080/10641734.2007.10505217

Reid, L. N., Salmon, C., \& Soley, L. C. (1984). The nature of sexual content in television advertising. Proceedings of the American Marketing Association, Chicago, IL, 214-216.

Reidenbach, R. E., \& Mc Cleary, K. W. (1983). Advertising and male bareness: An experimental investigation. Journal of Marketing, 19(4), 51-62.

Roussel, P., Durrieu, F., Campoy, E., \& El Akremi, A. (2002). Methodes d'Equations Structurelles: Recherche et Application en Gestion. Paris: Editions Economica, Collection Recherche en Gestion.

Sabri, O. (2012). Preliminary investigation of the communication effects of "taboo" themes in advertising. European Journal of Marketing, 46(1/2), 215-236. http://dx.doi.org/10.1108/03090561211189301

Sabri, O., \& Obermiller, C. (2011). Consumer perception of taboo in ads. Journal of Business Research, 65(6), 896-873. http://dx.doi.org/10.1016/j.jbusres.2011.01.009

Sciglimpaglia, D., Belch, M. A., \& Cain, R. F. (1979). Demographic and cognitive factors influencing Viewers' evaluations of 'sexy' advertisements. Advances in Consumer Research, 6, 62-65.

Sengupta, J., \& Dahl, W. D. (2008). Gender-related reactions to gratuitous sex appeals in advertising. Journal of Consumer Psychology, 18(1), 62-78. http://dx.doi.org/10.1016/j.jcps.2007.10.010

Sherman, C., \& Quester, P. (2005). The influence of product/bareness congruence on advertising effectiveness. Journal of Promotion Management, 11(2/3), 61. http://dx.doi.org/10.1300/J057v11n02_06

Shimp, T. A. (1981). Attitude toward the Ad as a mediator of consumer brand choice. Journal of Advertising, 10(2), 9-15. http://dx.doi.org/10.1080/00913367.1981.10672756

Shiv, B., Edell, J. A., \& Payne, J. W. (1997). Factors affecting the impact of negatively and positively framed ad messages. Journal of Consumer Research, 24(3), 285-294. http://dx.doi.org/10.1086/209510

Simmel, G. (1959). Sociology of Religion. New York: Philosophical library.

Simpson, P. M., Horton, S., \& Brown, G. (1996). Male bareness in advertisements: a modified and extension of gender and product effects. Journal of the Academy of Marketing Science, 24(3), 257-262. http://dx.doi.org/10.1177/0092070396243006

Singh, S., \& Churchill, G. A. (1987). Arousal and advertising effectiveness. Journal of Advertising, 16(1), 46-54. http://dx.doi.org/10.1080/00913367.1987.10673054

Singhapakdi, A., Marta, J. K., Rallapali, K. C., \& Rao, C. P. (2000). Toward understanding of religiousness and marketing ethics: An empirical study. Journal of Business Ethics, 27(4), 305-320. http://dx.doi.org/10.1023/A:1006342224035

Singhapakdi, A., Vittell, S. J., \& Franke, G. R. (1999). Antecedents, consequences and mediating effects of perceived moral intensity and personal moral philosophies. Journal of the Academy of Marketing Science, 27(1), 19-35. http://dx.doi.org/10.1177/0092070399271002

Smith, S. M., Haugtvedt, C. P., Jadrich, J. M., \& Anton, M. R. (1995). Understanding responses to sex appeals in advertising: an individual differences approach. Advances in Consumer Research, 22(1), 735-739.

Soley, L., \& Kurzbard, G. (1986). Sex in advertising: A comparison of 1964 and 1984 magazine advertisements. Journal of Advertising, 15(3), 46-54. http://dx.doi.org/10.1080/00913367.1986.10673018

Stayman, D. M., Douglas, M., \& Aaker, D. A. (1988). Are all the effects of feeling mediated by Aad? Journal of Consumer Research, 15(3), 368-373. http://dx.doi.org/10.1086/209173

Stedman, M. (1969). How sexy illustration affect brand recall. Journal of Advertising Research, 9(1), 15-19.

Steiger, J. H. (1990). Structural model evaluation and modification: an interval estimation approach. Multivariate Behaviour Research, 25(2), 173-180. http://dx.doi.org/10.1207/s15327906mbr2502_4

Tarrit, J. M. (1987). La médiatique: Le Traitement Publicitaire Des Médias. Paris: Editions Chotard. 
Thayer, R. E. (1986). Activation-deactivation adjective checklist: current overview and structural analysis. Psychological Reports, 58(2), 607-614. http://dx.doi.org/10.2466/pr0.1986.58.2.607

Vézina, R., \& Paul, O. (1997). Provocation in Advertising: A Conceptualization and an Empirical Assessment. International Journal of Research in Marketing, 14(2), 177-192. http://dx.doi.org/10.1016/S0167-8116(97)00002-5

Wansink, B., Cheney, M. M., \& Chan, N. (2003). Exploring confort food preferences across age and gender. Psychology and Behavior, 79, 739-747.

Watson, D., Clark, L. A., \& Tellegen, A. (1988). Development and validation of brief measures of positive and negative affect: the PANAS scales. Journal of Personality and Social Psychology, 54(6), 1063-1070. http://dx.doi.org/10.1037/0022-3514.54.6.1063

Wiles, J. A., \& Cornwell, T. B. (1990). A review of methods utilized in measuring affect, feeling and emotion in advertising. Current Issues and Research in Advertising, 13(2), 241-275.

Wilkes, R. E., Burnett, J. J., \& Howell, R. D. (1986). On the Meaning and Measurement of Religiosity in Consumer Research. Journal of the Academy of Marketing Science, 14(1), 47-57. http://dx.doi.org/10.1007/BF02722112

Worthington, E. L., Wade, N. G., Hight, T. L., McCullough, M. E., Berry, J. T., Ripley, J. S., ... Brusley, K. H. (2003). The religious commitment inventory-10: development, refinement and validation of a brief scale for research and counseling. Journal of Counseling Psychology, 50, 84-96. http://dx.doi.org/10.1037/0022-0167.50.1.84

\section{Copyrights}

Copyright for this article is retained by the author(s), with first publication rights granted to the journal.

This is an open-access article distributed under the terms and conditions of the Creative Commons Attribution license (http://creativecommons.org/licenses/by/3.0/). 